\title{
СИРИЙСКИЕ БЕЖЕНЦЫ В ЕВРОПЕ
}

Аннотация. Цель статьи - выявить социально-экономический контекст расселения сирийских беженцев в странах Европейского союза, так как именно сирийцы, обративииеся за убежищем в 2015-2016 г2., практически в 100\% случаев получали соответствующий статус международной защиты. На основе статистики и результатов сочиологических исследований автор делает вывод о незначительном влиянии притока беженцев на уровень безработищы или заработную плату в принимающих странах. В то же время большинство сирийских беженцев составляют молодые мужчины, которые конкурируют за рабочие места, как правило, с трудящимися того же возраста и образования. В этом случае влияние сирийцев $в$ отдельных секторах экономики на занятость молодых людей с низкой квалификацией оказывается значительным.

Ключевые слова: сирийцы, беженцы, секьютиризация миграчии, убежище, интеграция, безработица, Европейский союз, Германия, Швеция, рабочие места, профессиональное обучение.

Миграционный кризис или кризис беженцев, который испытала Европа, привёл к «секьютиризации» миграции, заставил рассматривать проблему миграции главным образом в контексте безопасности. Между тем, по мере ослабления притока беженцев и мигрантов и окончания острой фазы кризиса, на первый план в странах Евросоюза выходят его социально-экономические последствия, сегодняшние и долгосрочные.

По данным Агентства по оказанию содействия в получении убежища Евросоюза (АОСПУ), число претендентов в 2018 г. достигло показателей 2014 г. и оказалось на 10\% ниже, чем в 2017 г. Данные также демонстрируют снижение уровня удовлетворения ходатайств (34\% против 40\% в 2017 г.), отвергнуты были два заявления из трёх. В 2018 г. страны ЕС приняли 634700 человек, ищущих убежище. Сирия оставалась главным поставщиком потенциальных беженцев, но и их число снизилось на 25\% по сравнению с 2017 г. Один из десяти кандидатов на убежище был сирийцем в 2018 г., тогда как в 2015-2016 - один из четырёх. Афганцы и иракцы идут следующими в списке стран исхода претендентов на статус беженца, но в 2018 г. увеличилось количество обращений и от граждан других государств - Турции, Ирана, Венесуэлы, а также Грузии и Колумбии ${ }^{1}$.

Комиссия объявила о новой программе расселения 50 тыс. сирийцев по странам Европейского союза, высказав удовлетворение результатами действия договорённости ЕС с Турцией, заключённой в марте 2016 г. Турция в целом выполняет свои обязательства, несмотря на напряжённость в отношениях с Евросоюзом и периодические опасения, что «сделка» провалится. С тех пор, как она вступила в силу, миграционный поток на восточно-средиземно-

(C) Потемкина Ольга Юрьевна - доктор политических наук, главный научный сотрудник, руководитель Отдела исследований европейской интеграции ИЕ РАН. Адрес: 125009, Россия, Москва, ул. Моховая, д. 11, стр. 3.E-mail: olga_potemkina@mail.ru.

DOI: http://dx.doi.org/10.15211/vestnikieran320194853

1 EASOEU+ asylum trends2018 overview URL: https://www.easo.europa.eu/sites/default/files/EASO-2018-EUAsylum-Trends-Overview.pdf. 
морском направлении сократился почти на 97\%, в соответствии с данными Комиссии ${ }^{1}$. С другой стороны, статистика показывает, что сделка оказалась малоэффективной по двум важным направлениям: не были осуществлены массовые возвращения из Греции в Турцию (вернулись менее 2 тыс. пытавшихся проникнуть в Европу нелегально), а также не удалось создать легальный безопасный канал транспортировки ищущих убежище - число переселённых на законной основе из турецких лагерей в страны ЕС не достигло 3 тыс. И, наконец, сделка всё ещё может быть расторгнута, если Турция решит всё же настаивать на обещанном вознаграждении, помимо финансового. В этом случае Европу может ожидать ещё один кризис беженцев ${ }^{2}$.

Социологические опросы свидетельствуют, что в условиях возрастания притока беженцев из Сирии жители государств - членов Евросоюза полагали, что присутствие пришельцев может лишить их рабочих мест и усилить угрозу терроризма ${ }^{3}$. В Греции и Италии, например, большинство респондентов заявили, что их собственные страны превратятся в самые худшие места для проживания, если в них поселятся всё больше и больше представителей других рас, этнических групп и национальностей. Большинство респондентов в Германии, Греции, Италии и Великобритании согласились с утверждением, что приток беженцев увеличит вероятность террористических актов в их странах.

Ещё сильнее, чем ЕС, кризис поразил Турцию, так как большинство сирийцев в турецких городах вынуждены ютиться в трущобах, пребывая, таким образом, в изоляции, что увеличивает и ранее существовавший социальный разрыв между беженцами и местными жителями. Негативное отношение к сирийцам возрастает по мере того, как расширяются целые районы с ветхими и временными жилищами, а правительство вынуждено искать возможности обеспечить беженцам рабочие места, инфраструктуру, транспорт, школы, безопасность и другие социальные услуги.

Сирийцам как иммигрантам первого поколения в Европейском союзе в поисках работы приходится преодолевать множество препятствий - плохое знание языка принимающей страны, трудности в признании квалификации; национальность, религия и социальное положение также выступают в качестве барьеров на пути к интеграции в рынок труда, например, в Греции и Италии. Критерии, которые устанавливают принимающие страны для получения работы мигрантами, также уменьшают возможности трудоустройства. Например, в Германии при найме обращают внимание на «стремление приезжего следовать местному образу жизни», в Великобритании главное требование - знание английского языка.

\section{Экономические и социальные последствия притока сирийских беженцев в страны ЕC}

За 2014-2018 гг. в Европе статус беженца получили более 2 млн человек, и все они, по крайней мере, в ближайшей или среднесрочной перспективе, не собираются возвращаться домой. Более половины из них - люди трудоспособного возраста, которые могли бы быть интегрированы в рынки труда государств - членов Европейского союза. Статистика показывает, что «шок от наплыва беженцев» ${ }^{4}$, который испытали европейские государства, сильно

\footnotetext{
${ }^{1}$ Bulletin Quotidien Europe, №11856, 07.09.17.

${ }^{2}$ На территории Российской Федерации по состоянию на конец октября 2018 г., по данным МВД РФ, находилось 9,1 тыс. граждан Сирии. За прошедший год это число увеличилось на тысячу человек (на конец октября 2017 г. граждан Сирии в России было 8,1 тыс. чел.). В это число входят работники посольства с семьями, и те, кто приехал до начала войны.

${ }^{3}$ Pew Research Center, July, 2016, «Europeans Fear Wave of Refugees Will Mean More Terrorism, Fewer Jobs».

4 Borjas G. J., Monras J. «The labour market consequences of refugee supply shocks», Economic Policy, №32(91), 2017. П. 361-413.
} 
преувеличен, если соотнести их число с общими показателями населения стран ЕС. Даже в Шве-ции, которая приняла больше всего беженцев, их численность составила $2 \%$ от населения страны. По этой причине социологи отмечают незначительное влияние притока беженцев на уровень безработицы или заработную плату в принимающих странах.

С другой стороны, состав беженцев однородный, молодые люди, не обладающие квалификацией, составляют до трети всех сирийцев, прибывших в ЕС в 2014-2018 гг. В Германии молодые сирийцы активно заявили о себе на рынках труда: около 55\% прибывших в 2014 г. к 2016 г. уже получили работу или искали её ${ }^{1}$. Если учесть, что беженцы конкурируют за рабочие места в основном с трудящимися того же возраста и образования, то тогда влияние сирийцев в отдельных секторах экономики на занятость молодых людей с низкой квалификацией оказывается значительным. Нет сомнения, что этот фактор не способствует улучшению отношения к беженцам среди населения принимающих стран.

В соответствии с исследованиями германских центров IAB-BAMF-SOEP ${ }^{2}$, низкоквалифицированные мужчины и женщины в возрасте от 18 до 34 лет составляют 55\% недавно прибывших в страну беженцев трудоспособного возраста (18-64 года). Самая большая группа беженцев включает молодых низкоквалифицированных мужчин в возрасте от 18 до 34 лет, число которых достигает 30\% от всех приехавших в 2014-2018 гг. беженцев. Статистика ОЭСР свидетельствует об аналогичной структуре занятости сирийских беженцев и в других европейских странах ${ }^{3}$. Например, в Швеции, низкоквалифицированные молодые люди насчитывают $26 \%$ от всех сирийцев, недавно получивших статус беженца ${ }^{4}$. Таким образом, «шок от наплыва беженцев» испытывает в основном одна группа населения европейских стран: в Швеции численность низкоквалифицированных молодых людей, находящихся под международной защитой в 2014-2017 гг., достигает 20\% всех занятых того же возраста, пола и образования. Соответствующие данные по Германии немного ниже $-12 \% 5$.

Высокий уровень безработицы для молодых низкоквалифицированных рабочих наблюдается по всем странам Европейского союза: в 2017 г. уровень безработицы в этой группе составлял $18,9 \%$, при том, что соответствующие показатели трудоспособного населения в целом (15-64 лет) по всем странам были ниже - 7,8\%. Даже в Германии при уровне безработицы 3,8\%, доля безработных среди низкоквалифицированной молодёжи достигала 13,1\%. Кроме того, наблюдается очевидная гендерная сегментация на рынках труда среди низкоквалифицированных молодых людей. В преимущественно «мужских» отраслях экономики - производстве, строительстве, транспорте, где заняты более 70\% мужчин, насчитывается около 50\% низкоквалифицированных молодых мужчин в Германии и около $40 \%$ в Швеции. Если же принять во внимание сегментацию на рынках труда по показателям возраста и опыта работы, то конкуренция за рабочие места среди низкоквалифицированных молодых людей, несомненно, повышается в результате наплыва беженцев. Таким образом, данная демографическая группа испытывает значительное давление пришельцев на национальные рынки труда.

При этом в самой трудной ситуации могут оказаться «вчерашние» иммигранты, т.е. те, что прибыли ранее, до миграционного кризиса. Например, в Швеции около 20\% работающих

\footnotetext{
${ }^{1}$ Barslund M., Di Salvo M., Laurentsyeva N. The impact of refugees on the labour market: a big splash in a small pond? CEPS Working Document, №2018/07, October 2018. P. 3.

${ }^{2}$ Institute for Employment Research (IAB) of the German Federal Employment Agency (BA) Research Centre on Migration, Integration, and Asylum of the Federal Office for Migration and Refugees (BAMF-FZ).

OECD, International Migration Outlook 2018, OECD Publishing, Paris, 2018. URL: https://doi.org/10.1787/migr_out look-2018-en.

${ }_{5}^{4}$ Barslund M., Di Salvo M., Laurentsyeva N. Op. cit. P. 2.

5 Konle-Seidl, R. «Integration of refugees in Germany, Austria, and Sweden», study for the European Parliament's Committee on Employment and Social Affairs, 2018.
} 
молодых людей - иностранцы, и их число увеличивалось в последние годы, ещё до миграционного кризиса. Та же ситуации наблюдается и в других государствах - членах ЕС, отчасти и вследствие мобильности трудящихся внутри Евросоюза.

В долгосрочной перспективе возникает вопрос о доле низкоквалифицированных рабочих мест в экономике. Большой процент иммигрантов в определённых отраслях приводит к тому, что малооплачиваемые рабочие места теряют привлекательность для коренного населения принимающей страны и остаются вакантными. В этом случае недавно прибывшие сирийские беженцы могли бы заполнить образовавшийся вакуум и позволить местным рабочим перейти на более высокий уровень занятости. Однако многие низкоквалифицированные рабочие места в Европе находятся в зоне риска из-за усиливающейся конкуренции с развивающимися странами, где традиционно оплата труда значительно ниже, а также и из-за продолжающейся автоматизации производства и технологических перемен.

В последние годы численность низкоквалифицированных рабочих мест относительно общей занятости в ЕС существенно понизилась. В частности, эта ситуация характерна для производства - потенциально важной сферы занятости молодых беженцев. В то время как параллельно данной тенденции наблюдается скорее сокращение потребности, чем предложения низкоквалифицированной рабочей силы, статистика свидетельствует о снижении уровня занятости низкоквалифицированных рабочих во всех странах Европейского союза. Германия являет собой скорее исключение из общих правил, тогда как в Швеции уровень занятости низкоквалифицированных рабочих снизился на 10\% за последние 15 лет, особенно среди молодых рабочих.

Статистика занятости демонстрирует также более высокий уровень безработицы у сирийских беженцев сравнении с коренным населением в Греции, Италии, Великобритании. В Турции турки и сирийцы конкурируют за низкооплачиваемые работы, и большинство беженцев заняты в теневой экономике. Чтобы повысить уровень легальной занятости и создать стабильные рабочие места для беженцев, государственным и частным агентствам по найму рабочей силы приходится собирать данные о предыдущих местах их работы и квалификации.

\section{Практика интеграции беженцев в странах ЕС}

Несмотря на все препятствия, существующие обязательства правительств и помощь со стороны значительной части общества принимающих стран, в том числе, частное спонсорство, способствуют постепенной реализации планов расселения сирийцев. Примером для европейских стран служит Канада, где при участии не только правительства, но и различных компаний и организаций благополучно расселились 25 тыс. беженцев с перспективой интеграции их в канадское общество.

Существует риск, что сирийские беженцы так и останутся в категории низкооплачиваемых, малоквалифицированных рабочих с неопределёнными перспективами занятости. Если низкоквалифицированную работу выполняют преимущественно иностранцы, то разрыв меж-ду беженцами и местным населением возрастает, а вместе с тем и неприязнь с обеих сторон.

Германия, Австрия и Швеция вносят изменения в регулирование рынков труда и выполняют обязательства по интеграции беженцев, в том числе, организуют языковые курсы и пытаются учитывать ранее приобретённую квалификацию беженцев при трудоустройстве. Интеграционный закон 2016 г. в Германии позволил оптимизировать доступ беженцев на рынок труда, участие в интеграционных и языковых курсах, гарантировать проживание в течение нескольких лет. Взамен правительство требует определённых обязательств со стороны бежен-

Научно-аналитический вестник ИЕ РАН, 2019, №3 
цев - не уклоняться от предпринимаемых государством мер и проявить стремление к интеграции. В Италии же сирийские беженцы страдают от нежелания правительства выполнять свои международные обязательства, а также и незначительной общественной поддержки интеграции, включая и финансовую. Несмотря на некоторые усилия по обеспечению защиты беженцев, система предоставления убежища в Италии совершенствуется очень медленно, что отмечает, в частности, неправительственная организация «Врачи без границ». Чем хуже страна справляется с притоком мигрантов, тем быстрее растёт негативное отношение к ним со стороны населения.

В Великобритании сначала политика по отношению к сирийским беженцам сводилась к оказанию гуманитарной помощи. В начале 2014 г. правительство объявило о своём намерении активнее оказывать содействие сирийским беженцам и под давлением Палаты общин и международных организаций разработало специальную программу для сирийцев, находившихся в самом уязвимом положении. Благоприятная обстановка для сирийцев в Великобритании, как показал «Индекс интеграции мигрантов МIPЕХ», привела некоторых исследователей к выводу, что иммигранты получают больше шансов интегрироваться в общество принимающей страны, если политика правительства подкреплена позитивным или, по крайней мере, нейтральным отношением населения ${ }^{1}$.

Социологические исследования показывают, что молодые мигранты заняты в отраслях, которые в перспективе подвергнутся автоматизации. Им не предлагают пройти профессиональное обучение, и заключают временные контракты, без гарантии продления в случае технологической перестройки. При этом многие молодые беженцы демонстрируют высокую мотивацию продолжить образование, например, по данным IAM-BAMF-SOEP, в Германии почти 70\% молодых сирийцев стремятся к получению академической или профессиональной степени $^{2}$. Профессиональное обучение и повышение квалификации, так же, как и восстановление приобретённой ранее квалификации - важная составляющая интеграционных программ во многих странах. Но всё же важно понимать, что приобретение новых навыков и опыта работы требует много времени. Те же задачи социальной политики - профобразование и повышение квалификации - обращены и к другим неквалифицированным мигрантам, а также и местной молодёжи.

\section{Выводы}

Урегулирование кризиса беженцев требует от принимающих стран решения очень сложной проблемы - обеспечения занятости беженцев при минимальных негативных последствиях для коренного населения.

Социальная интеграция сирийцев предполагает их трудоустройство в формальном секторе экономики, иначе они не могут рассчитывать на достойные заработки и социальное обеспечение. В то же время выход беженцев в рынки труда принимающих стран может способствовать росту безработицы и сокращению доходов местного населения, что, без сомнения, усиливает негативное отношение к мигрантам. При разработке программ интеграции приходится иметь в виду данные конфликтующие цели с учётом социально-экономических и демографических показателей на региональном и местном, муниципальном уровнях.

Сирийские беженцы испытывают трудности социального и экономического характера, которые усугубляют друг друга. Некоторые исследователи полагают, что урегулирование кризиса беженцев зависит, прежде всего, от достижения социальной гармонии в принимающих

\footnotetext{
${ }^{1}$ Migrants' Integration Policy Index (MIPEX) URL: http://www.mipex.eu/key-findings.

${ }^{2}$ Barslund M., Di Salvo M., Laurentsyeva N. Op.cit. P. 6.
} 
странах. В то же время одним из главных критериев социальной интеграции считается успешное включение мигрантов в рынки труда, что делает необходимым учёт возможностей экономической интеграции при составлении социальных программ для беженцев.

\section{Список литературы}

Акопян Э.С., Кожина В.О. Миграционный кризис в Европе. Вестник МИЭП, №2(23), 2016. C. 25-31.

Миграционный кризис в Европе через призму статистических данных. Власть, №11, 2017. C. $169-175$.

\section{References}

Akopyan E.S., Kozhina V.O. Migracionnyj krizis v Evrope. Vestnik MIEP. №2(23), 2016. S. 25-31.

Migracionnyj krizis v Evrope cherez prizmu statisticheskih dannyh. Vlast’, №11, 2017. S. 169175.

Barslund M., Di Salvo M., Laurentsyeva N. The impact of refugees on the labour market: a big splash in a small pond? CEPS Working Document, №2018/07, October 2018.

Borjas G. J., Monras J. «The labour market consequences of refugee supply shocks», Economic Policy, №32(91), 2017. P. 361-413.

Konle-Seidl R. «Integration of refugees in Germany, Austria, and Sweden», study for the European Parliament's Committee on Employment and Social Affairs, 2018.

\section{Syrian refugees in Europe}

Author. Olga Potemkina, Doctor of Sciences (Politics), Head of the Department of European Integration Studies, Institute of Europe, Russian Academy of Science. Address: 11-3, Mokhovaya str., Moscow, Russia, 125009. E-mail: olga_potemkina@mail.ru.

Abstract. The article aims to define the socio-economic context of Syrian refugees' resettlement in the European Union Member States, as almost every Syrian in 2015-2016 received international protection in Europe. Based on statistics and sociological surveys, the author concludes that the influx of refugees has slightly affected unemployment or wages in the host countries. At the same time, the majority of Syrian refugees are young men who compete for jobs mainly with the workers of the same age and education. In this case, Syrians have influenced significantly employment of young people with low qualifications in the certain sectors of economy.

Keywords: Syrians, refugees, securitization of migration, asylum, integration, unemployment, jobs, European Union, Germany, Sweden, working places, training.

DOI: http://dx.doi.org/10.15211/vestnikieran320194853 